\title{
Pengaruh Edukasi Terhadap Pengetahuan Swamedikasi Batuk pada Anak di Kecamatan Wonosari Kabupaten Klaten Jawa Tengah
}

\section{The Effect of Education on Knowledge of Cough Self-Medication for Children in Wonosari District, Klaten Regency, Central Java}

\author{
Annisa Nur Safitri, Ika Purwidyaningrum, Inaratul Rizkhy Hanifah* \\ Fakultas Farmasi, Universitas Setia \\ BudiSurakarta \\ email: inaratul.rh.setiabudi@gmail.com
}

(tanggal diterima: 24-05-2021, tanggal disetujui: 19-10-2021)

\section{INTISARI}

Pengobatan sendiri atau swamedikasi merupakan salah satu cara masyarakat untuk mengobati suatu gejala penyakit tanpa menggunakan resep dari dokter. Pengetahuan akan swamedikasi yang benar sangat diperlukan agar penyakit dapat disembuhkan dengan tidak disertai efek lain yang merugikan penderita. Tujuan dari penelitian ini untuk mengetahui perbedaan pengetahuan orang tua sebelum dan sesudah pemberian edukasi swamedikasi serta mengetahui pengaruh edukasi melalui media online terhadap tingkat pengetahuan masyarakat tentang swamedikasi batuk pada anak di Kecamatan Wonosari, Kabupaten Klaten, Jawa Tengah pada tahun 2020.

Penelitian ini merupakan penelitian kuantitatif dengan metode penelitian Intervensi dengan teknik Two Group PreTest-PostTest Control Group Design. Populasi dalam penelitian ini adalah orang tua yang memiliki anak di Kecamatan Wonosari Kabupaten Klaten. Sampel dalam penelitian ini berjumlah 268 orang. Alat pengambilan data menggunakan kuesioner yang telah di uji validitas dan reliabilitasnya.

Hasil penelitian menunjukan bahwa tingkat pengetahuan masyarakat pada saat dilakukan pre-test tergolong baik $(41,04 \%)$, cukup $(54,48 \%)$, kurang $(4,48 \%)$, tidak baik $(0 \%)$. Pemberian edukasi mampu meningkatkan pengetahuan responden ditunjukan dengan hasil pengetahuan posttest tergolong baik $(89,55 \%)$, cukup $(10,45 \%)$, tidak baik $(0 \%)$, kurang $(0 \%)$. Analisis uji Wilcoxon didapatkan nilai p $0,000000<$ nilai $\alpha 0,05$ yang dapat diartikan bahwa pemberian edukasi melalui media online mempengaruhi pengetahuan masyarakat mengenai swamedikasi batuk pada anak.

Kata kunci : Swamedikasi; Edukasi; Batuk pada anak; Media online

\section{ABSTRACT}

Self-medication is one way for people to treat a symptom of a disease without using a prescription from a doctor. Knowledge of self-medication is needed so that symptoms can be cured without other adverse effects. The purpose of this study was to determine the difference in parental knowledge before and after self-medication education and to determine the effect of education through online media on the level of knowledge about cough self-medication in children in Wonosari District, Klaten Regency, Central Java in 2020.

This research is a quantitative study. The research method was an intervention study with the technique of Two Group Pre-Test-Post-Test Control Group Design. The population was parents who had children in Wonosari District, Klaten Regency. The sample in this study amounted to 268 people. The data collection tool uses a questionnaire that has been tested for validity and reliability.

The results showed that the level of public knowledge when the pre-test was carried out was classified as good $(41.04 \%)$, moderate (54.48\%), poor (4.48\%), not good (0\%). On the other hand, the provision of education was able to increase the respondent's knowledge as indicated by the results of post-test knowledge, which were classified as good (89.55\%), moderate (10.45\%), not 
good $(0 \%)$, poor $(0 \%)$. The Wilcoxon test analysis obtained a p-value of $0.000000<\alpha$ value of 0.05 , which means that education through online media affects public knowledge about cough selfmedication in children.

Keywords: Self-medication, Education, Cough in children, Online media

\section{PENDAHULUAN}

Pengobatan sendiri atau sering disebut dengan istilah self medication merupakan salah satu cara bagi masyarakat untuk mengobati suatu gejala penyakit tanpa menggunakan saran ataupun resep dari dokter. Dasar hukum swamedikasi adalah peraturan Menteri Kesehatan No. 919 Menkes/Per/X/1993. Swamedikasi merupakan salah satu upaya yang sering dilakukan oleh seseorang dalam mengobati gejala penyakit yang tanpa terlebih dahulu melakukan konsultasi kepada dokter [1]. Pelaksanaan swamedikasi memerlukan pengetahuan yang memadai agar tidak terjadi salah pengobatan (medication error) yang dampaknya merugikan diantaranya, tidak sembuhnya penyakit, semakin memburuk kondisi penyakit yang dialami, sehingga biaya pengobatan semakin meningkat. Dalam menerapkan swamedikasi terdapat beberapa kesalahan penggunaan obat terutama ketepatan obat dan dosis obat sehingga apabila dibiarkan dalam kurun waktu yang lama dapat menimbulkan risiko pada kesehatan [2].

Di-era global sekarang yang semakin mempermudah masyarakat untuk mendapatkan informasi sehingga dapat meningkatkan pengetahuan beberapa cara diantaranya yaitu dengan memberikan pendidikan kesehatan dan menggunakan media massa seperti booklet, leflet, flyer, flip chart, rubrik dan poster serta media elektronik seperti televisi, radio, video dan slide [3]. Memanfaatkan era global dimana mudah mendapatkan informasi dengan media elektronik sehingga dilakukan penelitian pengaruh edukasi terhadap pengetahuan swamedikasi obat batuk pada anak di Kecamatan Wonosari Kabupaten Klaten penelitian ini menggunakan metode intervensi yang dilakukan secara online menggunakan media elektronik. Kelebihan dari metode yang digunakan yaitu praktis dan fleksibel, pengisian dapat dilakukan dimana saja, edukasi dapat dilakukan sewaktu-waktu, lebih personal, alternatif selama social distancing.

Banyaknya kemudahan yang dibuat oleh industri farmasi membuat masyarakat lebih mudah untuk melakukan swamedikasi, kemudahan tersebut meliputi produk obat untuk swamedikasi semakin banyak. Semakin banyak produk bebas yang dirancang untuk swamedikasi dan beberapa produk obat yang telah dikenal sejak lama serta mempunyai indeks keamanan yang baik dan dimasukkan ke dalam kategori obat bebas [4]. Salah satu obat yang banyak diiklankan dan diperoleh tanpa resep dokter atau dikenal sebagai obat bebas (over the counter medicine) yaitu obat batuk. Jenis obat batuk bebas yang sering ada di pasaran adalah jenis ekspektoran, antitusif, atau kombinasinya. Diketahui bahwa obat batuk tidak bisa disamaratakan untuk semua jenis batuk yang diderita [5]. 
Menurut Hernawati, 2012, tidak rasionalnya penggunaan obat swamedikasi di dua apotek kemanggisan Depok disebabkan adanya efek samping yang mengganggu pada penggunaan obat responden sebesar 10,31\% ketidakpastian dosis obat yang diminum sebesar $8,25 \%$ dan polifarmasi 7,22\%. Dari penelitian sebelumnya disimpulkan bahwa masih minimnya tingkat pengetahuan masyarakat mengenai swamedikasi yang akan mempengaruhi pemilihan obat [6].

Batuk dalam bahasa latin disebut tussis adalah refleks yang dapat terjadi secara tiba-tiba dan sering berulang-ulang yang bertujuan untuk membantu membersihkan saluran pernapasan dari lendir besar, iritasi, partikel asing dan mikroba [7]. Ada dua jenis batuk yaitu batuk berdahak dan batuk kering. Batuk berdahak adalah batuk yang disertai dengan keluarnya dahak dari batang tenggorokan. Batuk kering adalah batuk yang tidak disertai keluarnya dahak. Batuk berdahak dapat diobati dengan obat ekspektoran (pengencer dahak) seperti gliseril guaiakolat, bromheksin, kombinasi gliseril guaiakolat dengan bromheksin dan obat batuk hitam, sedangkan batuk kering dapat diobati dengan obat penekan batuk (antitusif) yaitu dekstrometorfan, dan difenhidramin $\mathrm{HCl}$ [8].

Dalam masa pandemi Covid-19 ini para orang tua akan cenderung untuk melakukan swamedikasi dibandingkan berobat ke rumah sakit atau dokter dikarenakan rumah sakit ataupun klinik salah satu tempat yang rentan terhadap penularan virus. Berdasarkan latar belakang tersebut, maka penting dilakukan penelitian untuk mengetahui pengaruh edukasi terhadap pengetahuan swamedikasi batuk pada anak, agar dapat membantu masyarakat dalam pemilihan penggunaan obat yang terjangkau secara efektif penggunaannya.

\section{METODE PENELITIAN}

\subsection{Metode Penelitian}

Penelitian dilakukan secara online dengan membagikan link google form kepada masyarakat di Kecamatan Wonosari Kabupaten Klaten yang memenuhi kriteria inklusi berupa Masyarakat di Kecamatan Wonosari Kabupaten Klaten yang berusia 20-45 tahun, Memiliki anak $\leq 12$ tahun, Memiliki KTP (Kartu Tanda Penduduk) di Kecamatan Wonosari Kabupaten Klaten, berdomisili di Kecamatan Wonosari Kabupaten Klaten, Mampu menggunakan media digital dengan lancar dan bersedia menjadi responden serta kriteria eksklusi orang tua yang tidak memiliki anak dan tidak dalam keadaan sakit jiwa maupun fisik. Penelitian dilakukan selama bulan Agustus-September 2020. Penelitian ini sudah melalui perijinan etik dengan nomor Ethical Clearance 1.041/VIII/HREC/2020. Penelitian ini merupakan penelitian kuantitatif dengan metode penelitian intervensi dengan teknik Two Group Pre Test-Post Test Control Group Design. Penelitian ini dilakukan melalui pengukuran tingkat pengetahuan pada kelompok kontrol dan kelompok Intervensi (pre-test) serta pengukuran terhadap tingkat pengetahuan kelompok eksperimen setelah diberikan intervensi (post-test) berupa pemberian informasi dan edukasi melalui media online berupa poster dan video serta pengumpulan data melalui google form.

Sampel adalah bagian dari populasi yang dipilih dengan teknik sampling 
tertentu untuk bisa mewakili atau memenuhi populasi [9]. Pengambilan sampel dilakukan dengan teknik purposive sampling. Penentuan ukuran sampel dalam penelitian ini menggunakan rumus Isaac \& Michael dengan tingkat kesalahan 10\%.

Sampel yang dipilih yaitu masyarakat Kecamatan Wonosari, Klaten yang berusia 20-45 tahun dengan jumlah 268 responden. Kemudian dibagi menjadi dua kelompok yaitu kelompok kontrol dan kelompok perlakuan masing-masing 134 responden. Pada kelompok kontrol subjek diminta kesediaannya untuk menjadi responden dalam penelitian kemudian subjek diminta untuk mengisi kuesioner yang ada dalam google forms tanpa diberi edukasi. Pada kelompok perlakuan subjek diminta ketersediannya untuk menjadi responden dalam penelitian. Selanjutnya subjek diberi edukasi dengan media komunikasi elektronik berupa pemberian video, leaflet serta diskusi secara online dengan interval waktu 2 kali dalam seminggu selama 1 bulan kemudian subjek melanjutkan untuk mengisi kuesioner dalam google forms tersebut.

Tingkat pengetahuan dikategorikan menjadi 4 yaitu baik apabila responden mampu menjawab pertanyaan 76\% - 100\%, cukup baik apabila mampu menjawab $56 \%-75 \%$, kurang baik apabila menjawab $40 \%-55 \%$, dan tidak baik apabila menjawab < 40\% [10]. Data yang diperoleh dari setiap responden dianalisis dengan menggunakan Statistic Program For Social Science (SPSS) versi 21. Analisis data yang digunakan dalam penelitian ini yaitu Uji koefisien Validasi dan Reliabilitas, Uji Kolmogorov-Smirnov, Uji Paired-sample t test, dan Uji Wilcoxon untuk melihat perbedaan sebelum dan sesudah edukasi. Keputusan uji statistik menggunakan taraf signifikan $\mathrm{p}<0.05$.

\section{HASIL DAN PEMBAHASAN}

\subsection{Analisis Karakteristik Responden}

Sebanyak 268 responden yang terlibat dalam penelitian ini. Dibagi menjadi 2 kelompok yakni kelompok kontrol 134 responden dan kelompok perlakuan 134 responden. Karakteristik responden dalam penelitian ini meliputi usia, pendidikan, pekerjaan, cara memperoleh obat, dan informasi obat yang diperoleh.

Tabel 1. Distribusi Usia Responden

\begin{tabular}{|c|c|c|c|c|}
\hline \multirow[t]{2}{*}{ Umur } & \multicolumn{2}{|c|}{ Kelompok Kontrol } & \multicolumn{2}{|c|}{ Kelompok Perlakuan } \\
\hline & $\begin{array}{l}\text { N (Jumlah } \\
\text { Responden) }\end{array}$ & $\begin{array}{c}\text { Persentase } \\
\text { (\%) }\end{array}$ & $\begin{array}{l}\text { N (Jumlah } \\
\text { Responden) }\end{array}$ & $\begin{array}{c}\text { Persentase } \\
(\%)\end{array}$ \\
\hline 20-24 Tahun & 33 & 24,63 & 35 & 26,11 \\
\hline 25 - 29 Tahun & 44 & 32,83 & 41 & 30,59 \\
\hline $30-34$ Tahun & 31 & 23,13 & 33 & 24,62 \\
\hline 35 - 39 Tahun & 18 & 13,43 & 13 & 9,70 \\
\hline 40 - 44 Tahun & 8 & 5,79 & 12 & 8.59 \\
\hline 45 - 49 Tahun & 0 & 0 & 0 & 0 \\
\hline Jumlah & 134 & 100 & 134 & 100 \\
\hline
\end{tabular}

Dari penelitian diperoleh hasil, usia responden terbanyak pada rentang 25-29 tahun, hal ini dikarenakan responden di usia ini lebih aktif untuk menggunakan media komunikasi online dibandingkan responden pada rentang usia lain. Selain 
itu pada rentang usia tersebut responden akan lebih mudah untuk menerima pengetahuan dan informasi baru dari edukasi yang dilakukan melalui media komunikasi online karena masih memiliki daya ingat yang masih baik. sedangkan pada usia lanjut kemampuan responden untuk menerima informasi kurang karena seiring bertambahnya usia daya ingatnya juga akan semakin berkurang hal ini sejalan dengan penelitian terdahulu yakni sebanyak 83,0\% responden yang berusia 18-28 tahun melakukan pengobatan sendiri karena mendapatkan informasi dari Tenaga Medis [11].

Tabel 2. Distribusi Pendidikan Responden

\begin{tabular}{|l|c|c|c|c|}
\hline \multicolumn{1}{|c}{ Pendidikan } & \multicolumn{2}{c|}{ Kelompok Kontrol } & \multicolumn{2}{c|}{ Kelompok Perlakuan } \\
\cline { 2 - 5 } & $\begin{array}{c}\text { N (Jumlah } \\
\text { Responden) }\end{array}$ & $\begin{array}{c}\text { Persentase } \\
\text { (\%) }\end{array}$ & $\begin{array}{c}\text { N (Jumlah } \\
\text { Responden) }\end{array}$ & $\begin{array}{c}\text { Persentase } \\
\text { (\%) }\end{array}$ \\
\hline Tamat SD Sederajat & 2 & 1,2 & 4 & 2,98 \\
\hline Tamat SMP Sederajat & 7 & 4,9 & 4 & 2,98 \\
\hline Tamat SMA Sederajat & 88 & 65,9 & 82 & 61,19 \\
\hline Perguruan Tinggi & 37 & 28 & 44 & 32,83 \\
\hline Jumlah & $\mathbf{1 3 4}$ & $\mathbf{1 0 0}$ & $\mathbf{1 3 4}$ & $\mathbf{1 0 0}$ \\
\hline
\end{tabular}

Dari data yang didapatkan responden terbanyak adalah tamat SMA sederajat dengan nilai 65,9\% hal ini sejalan dengan penelitian Restiyono (2016) bahwa tidak terdapat hubungan Pendidikan dengan swamedikasi karena meskipun tingkat Pendidikan yang dimiliki tinggi tetapi kurangnya sosialisasi mengenai swamedikasi menjadikan masyarakat tidak memahami dengan baik mengenai swamedikasi sehingga masih banyak yang melakukan swamedikasi secara sembarangan [12].

Tabel 3. Distribusi Pekerjaan Responden

\begin{tabular}{|l|c|c|c|c|}
\hline \multicolumn{1}{|c}{ Pekerjaan } & \multicolumn{2}{c|}{ Kelompok Kontrol } & \multicolumn{2}{c|}{ Kelompok Perlakuan } \\
\hline & $\begin{array}{c}\text { N (Jumlah } \\
\text { Responden) }\end{array}$ & $\begin{array}{c}\text { Persentase } \\
\text { (\%) }\end{array}$ & $\begin{array}{c}\text { N (Jumlah } \\
\text { Responden) }\end{array}$ & $\begin{array}{c}\text { Persentase } \\
\text { (\%) }\end{array}$ \\
\hline Tidak/belum bekerja & 2 & 1,7 & 9 & 7 \\
\hline Karyawan Swasta & 49 & 36,6 & 44 & 32,6 \\
\hline Mahasiswa & 3 & 2 & 12 & 8,1 \\
\hline Pegawai Negeri Sipil & 25 & 19,4 & 24 & 18,2 \\
(PNS) & & & & \\
\hline Ibu Rumah Tangga & 54 & 40,29 & 45 & 34,1 \\
\hline Jumlah & $\mathbf{1 3 4}$ & $\mathbf{1 0 0}$ & $\mathbf{1 3 4}$ & $\mathbf{1 0 0}$ \\
\hline
\end{tabular}

Responden terbanyak yaitu ibu rumah tangga dengan nilai 40,29\% dimana dalam swamedikasi ibu rumah tangga lebih banyak melakukan swamedikasi dikarenakan pengobatan dengan swamedikasi dirasa lebih praktis dan tidak mengganggu aktivitas pekerjaan (13).

Data didapatkan hasil terbanyak yaitu Apotek hal ini disebabkan karena banyaknya berita mengenai pemalsuan obat yang dilakukan beberapa oknum sehingga masyarakat mulai menyadari untuk mendapatkan obat sesuai dengan tempatnya yaitu apotek, 
Tabel 4. Cara Memperoleh Obat

\begin{tabular}{|l|c|c|c|c|}
\hline Cara Memperoleh Obat & \multicolumn{2}{|c|}{ Kelompok Kontrol } & \multicolumn{2}{c|}{ Kelompok Perlakuan } \\
\cline { 2 - 5 } & $\begin{array}{c}\text { N (Jumlah } \\
\text { Responden) }\end{array}$ & $\begin{array}{c}\text { Persentase } \\
\text { (\%) }\end{array}$ & $\begin{array}{c}\text { N (Jumlah } \\
\text { Responden) }\end{array}$ & $\begin{array}{c}\text { Persentase } \\
\text { (\%) }\end{array}$ \\
\hline Apotek & 103 & 77,3 & 125 & 93,3 \\
\hline Warung & 14 & 10,6 & 2 & 1,2 \\
\hline Toko Obat & 6 & 3,9 & 4 & 2,7 \\
\hline Supermarket & 8 & 6,1 & 2 & 1,9 \\
\hline Lainnya & 3 & 2,1 & 1 & 0,9 \\
\hline Jumlah & $\mathbf{1 3 4}$ & $\mathbf{1 0 0}$ & $\mathbf{1 3 4}$ & $\mathbf{1 0 0}$ \\
\hline
\end{tabular}

toko obat sesuai dengan Peraturan Menteri Kesehatan Republik Indonesia Nomor 1148/MENKES/PER/VI/2011 untuk menjamin keaslian obat yang didapatkan. Berdasarkan penelitian yang dilakukan Sasmita M.A.R (2018) sebanyak $86 \%$ responden mendapatkan obat di apotek [14].

Tabel 5. Distribusi Sumber Informasi Obat Yang Diperoleh

\begin{tabular}{|l|c|c|c|c|}
\multicolumn{1}{|c}{$\begin{array}{c}\text { Cara Memperoleh } \\
\text { Informasi Obat }\end{array}$} & $\begin{array}{c}\text { Kelompok Kontrol } \\
\text { N (Jumlah } \\
\text { Responden) }\end{array}$ & $\begin{array}{c}\text { Persentase } \\
\text { (\%) }\end{array}$ & $\begin{array}{c}\text { Kelompok Perlakuan } \\
\text { Nesponden) }\end{array}$ & $\begin{array}{c}\text { Persentase } \\
\text { (Jo) }\end{array}$ \\
\hline Keluarga & 31 & 23,5 & 17 & 12,7 \\
\hline Sosial Media & 13 & 9,8 & 7 & 5,2 \\
\hline Tenaga Kesehatan & 54 & 40,2 & 67 & 50 \\
\hline Iklan & 33 & 24,2 & 40 & 29,9 \\
\hline Lainnya & 3 & 2,3 & 3 & 2,2 \\
\hline Jumlah & $\mathbf{1 3 4}$ & $\mathbf{1 0 0}$ & $\mathbf{1 3 4}$ & $\mathbf{1 0 0}$ \\
\hline
\end{tabular}

Berdasarkan data yang didapatkan sumber informasi terbanyak dilakukan oleh Tenaga Kesehatan dengan nilai persentase $40,4 \%$ hal ini sejalan dengan penelitian terdahulu yakni sebanyak $75 \%$ responden melakukan pengobatan sendiri karena mendapatkan informasi dari Tenaga Medis (15).

\subsection{Tingkat Pengetahuan Responden}

Hasil yang diperoleh menunjukkan bahwa tingkat pengetahuan swamedikasi batuk pada anak meningkat setelah diberikan edukasi selama 1 bulan.

Tabel 6. Distribusi Tingkat Pengetahuan Swamedikasi

\begin{tabular}{|l|c|c|c|c|}
\hline \multicolumn{1}{|c}{$\begin{array}{c}\text { Tingkat Pengetahuan } \\
\text { Swamedikasi }\end{array}$} & $\begin{array}{c}\text { Pretest } \\
\text { Nesponden) }\end{array}$ & $\begin{array}{c}\text { Persentase } \\
\text { (\%) }\end{array}$ & $\begin{array}{c}\text { N (Jumlah } \\
\text { Responden) }\end{array}$ & $\begin{array}{c}\text { Persentase } \\
\text { (\%) }\end{array}$ \\
\hline Baik (76\%- 100\%) & 57 & 42,54 & 117 & 87,31 \\
\hline Cukup (56\%- 75\%) & 72 & 53,73 & 17 & 12,68 \\
\hline Tidak Baik (0\%- & 5 & 3,73 & 0 & 0 \\
\hline $\mathbf{5 5 \% )}$ & 0 & 0 & 0 & 0 \\
\hline Kurang (<40\%) & $\mathbf{4 3 4}$ & $\mathbf{1 0 0}$ & $\mathbf{1 3 4}$ & $\mathbf{1 0 0}$ \\
\hline Jumlah & & & & \\
\hline
\end{tabular}


Dapat dilihat dari jumlah responden dalam kategori baik lebih besar daripada kategori cukup serta dalam kategori tidak baik maupun kurang tidak terdapat sehingga hal ini dapat menandakan bahwa informasi yang diberikan melalui media elektronik dapat meningkatkan pengetahuan masyarakat akan pengetahuan umum mengenai swamedikasi.

Tabel 7. Distribusi Tingkat Pengetahuan Swamedikasi Batuk

\begin{tabular}{|l|c|c|c|c|}
\hline \multicolumn{1}{|c}{$\begin{array}{c}\text { Tingkat Pengetahuan } \\
\text { Swamedikasi Batuk }\end{array}$} & $\begin{array}{c}\text { N (Jumlah } \\
\text { Responden) }\end{array}$ & $\begin{array}{c}\text { Persentase } \\
\text { (\%) }\end{array}$ & $\begin{array}{c}\text { N (Jumlah } \\
\text { Responden) }\end{array}$ & $\begin{array}{c}\text { Persentase } \\
\text { (\%) }\end{array}$ \\
\hline Baik (76\% - 100\%) & 55 & 41,04 & 120 & 89,55 \\
\hline Cukup (56\%- 75\%) & 73 & 54,48 & 14 & 10,45 \\
\hline Tidak Baik (0\%-55\%) & 6 & 4,48 & 0 & 0 \\
\hline Kurang (< 40\%) & 0 & 0 & 0 & 0 \\
\hline Jumlah & $\mathbf{1 3 4}$ & $\mathbf{1 0 0}$ & $\mathbf{1 3 4}$ & $\mathbf{1 0 0}$ \\
\hline
\end{tabular}

Berdasarkan data penelitian yang didapatkan di Kecamatan Wonosari Kabupaten Klaten hasil post-test didapatkan peningkatan dibandingkan dari hasil pre-test yang didapat hal ini menandakan bahwa pemberian informasi edukasi melalui media elektronik berupa pemberian video serta pemberian leaflet dapat meningkatkan pengetahuan masyarakat mengenai pengetahuan swamedikasi batuk pada anak.

Tabel 8. Distribusi Sikap Responden Dalam Swamedikasi Batuk

\begin{tabular}{|l|c|c|c|c|}
\hline \multicolumn{1}{|c|}{$\begin{array}{c}\text { Tingkat Pengetahuan } \\
\text { Swamedikasi Batuk }\end{array}$} & $\begin{array}{c}\text { N (Jumlah } \\
\text { Responden) }\end{array}$ & $\begin{array}{c}\text { Persentase } \\
\text { (\%) }\end{array}$ & $\begin{array}{c}\text { N (Jumlah } \\
\text { Responden) }\end{array}$ & $\begin{array}{c}\text { Persentase } \\
\text { (\%) }\end{array}$ \\
\hline Baik (76\%- 100\%) & 63 & 47,01 & 127 & 94,78 \\
\hline Cukup (56\%- 75\%) & 67 & 50 & 7 & 5,22 \\
\hline Tidak Baik (0\%-55\%) & 4 & 2,99 & 0 & 0 \\
\hline Kurang (<40\%) & 0 & 0 & 0 & 0 \\
\hline Jumlah & $\mathbf{1 3 4}$ & $\mathbf{1 0 0}$ & $\mathbf{1 3 4}$ & $\mathbf{1 0 0}$ \\
\hline
\end{tabular}

Sesudah pemberian edukasi pada data post-test diketahui bahwa terjadi peningkatan perilaku responden yaitu tidak ada responden dengan sikap yang kurang (0\%), tidak baik (0\%), cukup sebanyak 7 orang $(5,22 \%)$, dan perilaku masyarakat yang baik sebanyak 127 orang (94,78\%). Hal ini menandakan bahwa informasi dapat meningkatkan sikap dalam swamedikasi obat batuk pada anak.

Sesudah pemberian edukasi pada data post-test diketahui bahwa terjadi peningkatan perilaku responden yaitu tidak ada responden dengan perilaku yang kurang $(0 \%)$, tidak baik $(0 \%)$, cukup sebanyak 6 orang $(4,47 \%)$, dan perilaku masyarakat yang baik sebanyak 128 orang (95,52\%). Hal ini berarti pemberian informasi dalam bentuk pemberian edukasi melalui media komunikasi elektronik dapat meningkatkan perilaku masyarakat tentang swamedikasi batuk pada anak. 
Tabel 9. Distribusi Perilaku Responden Dalam Swamedikasi Batuk

\begin{tabular}{|l|c|c|c|c|}
\multicolumn{1}{|c}{$\begin{array}{c}\text { Distribusi Perilaku } \\
\text { Responden }\end{array}$} & $\begin{array}{c}\text { Pretest } \\
\text { Nesponden) }\end{array}$ & $\begin{array}{c}\text { Persentase } \\
\text { R\%) }\end{array}$ & $\begin{array}{c}\text { N (Jumlah } \\
\text { Responden) }\end{array}$ & $\begin{array}{c}\text { Persentase } \\
\text { (\%) }\end{array}$ \\
\hline Baik (76\% - 100\%) & 61 & 45,52 & 128 & 95,52 \\
\hline Cukup (56\% - 75\%) & 69 & 51,49 & 6 & 4,48 \\
\hline $\begin{array}{l}\text { Tidak Baik (0\%) } \\
\text { 55\%) }\end{array}$ & 4 & 2,99 & 0 & 0 \\
\hline Kurang (<40\%) & 0 & 0 & 0 & 0 \\
\hline Jumlah & $\mathbf{1 3 4}$ & $\mathbf{1 0 0}$ & $\mathbf{1 3 4}$ & $\mathbf{1 0 0}$ \\
\hline
\end{tabular}

\subsection{Pengaruh Edukasi Terhadap Tingkat Pengetahuan Responden}

Pengetahuan orang tua mengenai swamedikasi batuk dalam penelitian ini meliputi definisi batuk, macam-macam batuk, penyebab batuk, cara penanganan batuk, tatalaksana batuk, cara pemilihan obat batuk, cara penyimpanan, dosis obat, efek samping obat, kadaluarsa dan obat rusak, dan cara pembuangan obat, mengenai sifat dan perilaku responden dalam melaksanakan swamedikasi obat batuk pada anak.

Analisis yang dilakukan untuk mengetahui pengaruh edukasi terhadap tingkat pengetahuan swamedikasi batuk dilakukan secara deskriptif dengan menggunakan uji Wilcoxon. Berdasarkan hasil uji Wilcoxon diperoleh nilai p dari uji hipotesis dua sisi (two-tailed test) adalah 0,000 dimana nilai yang diperoleh lebih kecil dari nilai $\alpha$ 0,05 sehingga dapat diartikan bahwa pemberian edukasi melalui media online yang didapat dapat oleh responden melalui pre-test dan posttest mempengaruhi pengetahuan masyarakat mengenai pengetahuan swamedikasi batuk pada anak.

Berdasarkan penelitian Pratiwi (2017) [16] juga membuktikan bahwa terdapat perbedaan yang signifikan antara tingkat tingkat pengetahuan sebelum dan sesudah edukasi dan tingkat pengetahuan sesudah edukasi dengan nilai $\mathrm{p}$ $0,004(, 0,05)$. Penelitian yang dilakukan oleh Mawaddah R (2018) [17] terdapat perbedaan antara responden yang telah diberikan edukasi sehingga edukasi berpengaruh pada tingkat pengetahuan swamedikasi batuk dengan nilai p 0,000< 0,05 .

\section{KESIMPULAN}

Terdapat perbedaan pengetahuan orang tua di Kecamatan Wonosari Kabupaten Klaten sebelum dan sesudah diberikan perlakuan berupa edukasi swamedikasi obat batuk pada anak. Terdapat Pengaruh edukasi terhadap pengetahuan orang tua di Kecamatan Wonosari Kabupaten Klaten dalam swamedikasi obat batuk pada anak.

\section{DAFTAR PUSTAKA}

[1]. Pratiwi P.N., L. Pristianty dan G.N.A Impian. 2014. Pengaruh Pengetahuan Terhadap Perilaku Swamedikasi Obat Anti-Inflamasi Non-Steroid Oral pada Etnis Thionghoa di Surabaya. Jurnal Farmasi Komunitas 1(2). 36-40 
[2]. Supardi dan Notosuwiryo. 2005. Pengobatan sendiri sakit kepala, batuk dan pilek pada masyarakat desa Ciwalan Kecamatan Warungkondang Kabupaten Cianjur, Jawa Barat. Majalah Ilmu Kefarmasia 2(134-144).

[3]. Nur Aini H., Khairunnisa, J. Tanuwijaya. 2017. Tingkat Pengetahuan Pasien dan Rasionalitas Swamedikasi di Tiga Apotek Kota Penyambungan, Jurnal Sains dan Klinis. Ikatan Apoteker Indonesia. Sumatera Barat.

[4]. Ipang dan Y.Dian. 2011. Swamedikasi yang Baik dan Benar. Citra Aji Pamara. Yogyakarta.

[5]. Meriati E.K.W.N., Goenawi R.L., Wiyono W. 2013. Dampak Penyuluhan Pada Pengetahuan Masyarakat Terhadap Pemilihan Dan Penggunaan Obat Batuk Swamedikasi Di Kecamatan Malalayang. Jurnal Ilmiah Farmasi 2(03).

[6]. Hernawati, D. 2012. Pengaruh Edukasi Terhadap tingkat Pengetahuan Dan Rasionalitas Penggunaan Obat Swamedikasi Pengunjung Di Dua Apotek Di Kecamatan Cimanggis Depok, Fakultas MIPA Program Studi Farmasi. Depok.

[7]. Herdyani, P. dan S. Soemarno. 2013. Perbedaan Postural Drainage dan Latihan Batuk Efektif pada Intervensi Nabulizer Terhadap Penurunan Frekuensi Batuk pada Asma Bronchiale Anak Usia 3-5 Tahun. Jurnal Fisioterapi 13(1).

[8]. Departemen Kesehatan Republik Indonesia (Depkes RI). 2007. Pedoman Pelayanan Kefarmasisan di Puskesmas. Depkes RI. Jakarta.

[9]. Nursalam (2003). Konsep dan Penerapan Metodologi Penelitian Ilmu Keperawatan Pedoman Skripsi, Tesis dan Instrumen Penelitian Keperawatan. Jakarta : Salemba Medika.

[10]. Nurtiana I.S., Hidayati, I.R., dan Pristianty L. 2017. Hubungan Tingkat Pengetahuan terhadap Penggunaan Obat Parasetamol Rasional dalam Swamedikasi. Jurnal Farmasi Dan Ilmu Kefarmasian Indonesia 4(1).

[11]. Nur Aini H., Khairunnisa, J. Tanuwijaya. 2017. Tingkat Pengetahuan Pasien dan Rasionalitas Swamedikasi di Tiga Apotek Kota Penyambungan, Jurnal Sains dan Klinis. Ikatan Apoteker Indonesia. Sumatera Barat.

[12]. Restiyono, A. 2016. Analisis Faktor yang Berpengaruh dalam Swamedikasi Antibiotik pada Ibu Rumah Tangga di Kelurahan Kajen Kebupaten Pekalongan. Jurnal Promosi Kesehatan Indonesia.Vol. 11.

[13]. Sasmita MAR. 2018. Profil Swamedikasi Pada Mahasiswa Universitas Muhammadiyah Surakarta Periode November-Desember 2017. Fakultas Farmasi. Universitas Muhammadiyah Surakarta.

[14]. Siahaan S, Usia T., Pujiati S , Ingan Tarigan I,U. 2017. Pengetahuan, Sikap, dan Perilaku Masyarakat dalam Memilih Obat yang Aman di Tiga Provinsi di Indonesia Knowledge, Attitude, and Practice of Communities on Selecting Safe Medicines in Three Provincies in Indonesia. jurnal Kefarmasian Indonesia. (2):136-145.

[15]. Pratiwi P.N., L. Pristianty dan G.N.A Impian. 2014. Pengaruh Pengetahuan Terhadap Perilaku Swamedikasi Obat Anti-Inflamasi Non-Steroid Oral pada Etnis Thionghoa di Surabaya. Jurnal Farmasi Komunitas 1(2). 36-40 
[16]. Mawaddah R. 2018. Pengaruh Edukasi Terhadap Tingkat Pengetahuan Swamedikasi Batuk Pada Santri SMA Pasantren Darul Khoirot Sunan Bonang Pasuruan. Fakultas Ilmu Kedokteran dan Kesehatan. Universitas Islam Negeri Maulana Malik Ibrahim. 